Radioactivity and uranium content of the Sharon Springs member of the Pierre shale and associated rocks in western Kansas and eastern Colorado

By E. R. Landis

U. S. GEOLOGICAL SURVEY Field Library Albuquerque, New Mexico

Trace Elements Investigations Report 573

UNITED STATES DEPARTMEINT OF THE INTERIOR GEOLOGICAL SURVEY 

Geology and Mineralogy

This document consists of 38 pages, plus 3 figures.

Series A

UNITED STATES DEPARTMENT OF THE INTERIOR

GEOLOGICAL SURVEY

\section{RADIOACTIVITY AND URANIUM CONTENT OF THE SHARON SPRINGS \\ MEMBER OF THE PIERRE SHALE AND ASSOCIATED ROCKS \\ IN WESTERN KANSAS AND EASTERN COLORADO*}

By

E. R. Landis

December 1955

Trace Elements Investigations Report 573

This preliminary report is distributed without editorial and technical review for conformity with official standards and nomenclature. It is not for public inspection or quotation.

* This report concerns work done on behalf of the Division of Raw Materials of the U. S. Atomic Energy Commission. 
USGS - TEI-573

GEOLOGY AND MINERALOGY

Distribution (Series A)

No. of copies

Atomic Energy Commission, Washington . . . . . . .

Division of Raw Materials, Albuquerque . . . . . . . 1

Division of Raw Materials, Austin . . . . . . . . 1

Division of Raw Materials, Butte . . . . . . . . . 1

Division of Raw Materials, Casper . . . . . . . . 1

Division of Raw Materials, Denver . . . . . . . . 1

Division of Raw Materials, Hot Springs . . . . . . . 1

Division of Raw Materials, Ishpeming . . . • . . . 1

Division of Raw Materials, Phoenix . . . . . . . . 1

Division of Raw Materialı, Sť. George . . . . . . . I

Division of Raw Materials, Salt Lake City . • . . • . I

Division of Raw Materials, Washington . . . . . . 3

Exploration Division, Grand Junction Operations Office . . 1

Grand Junction Operations Office . . . . . . . . . 1

Technic al Information Service, Oak Ridge . . . . . 6

U. S. Geological Survey:

Fuels Branch, Washington. . . . . . . . . . . 3

Geochemistry and Petrology Branch, Washington. . . . 1

Geophysics Branck, Washington . . . . . . . . . 1

Mineral Deposits Branch, Washington . . . . . . . 1

P. C. Bateman, Menlo Park . . . . . . . . . . . I

A. L. Brokaw, Grand Juriction . . . . . . . . . . 1

N. M. Denson, Denver . . . . . . . . . . . 2

V. L. Freeman, College . . . . . . . . . . . . 1

R. L. Griggs, Albuquerque . . . . . . . . . . 1

M. R. Klepper, Spokane . . . . . . . . . . . . 1

A. H. Koschmann, Denver . . . . . . . . . . . 1

J. D. Love, Laramie . . . . . . . . . • . . . 1

L. R. Page, Washington . . . . . • . . . . . . 1

Q. D. Singewald, Beltsville . . . . . . . . . . . 1

A. E. Weissenborn, Spokane . . . . . . . . . 1

TEPCO, Denver . . . . . . . . . . . . . . . 2

TEPCO, RPS, Washington (including master) • . . . $\frac{2}{45}$ 


\section{CONTENTS}

\section{Page}

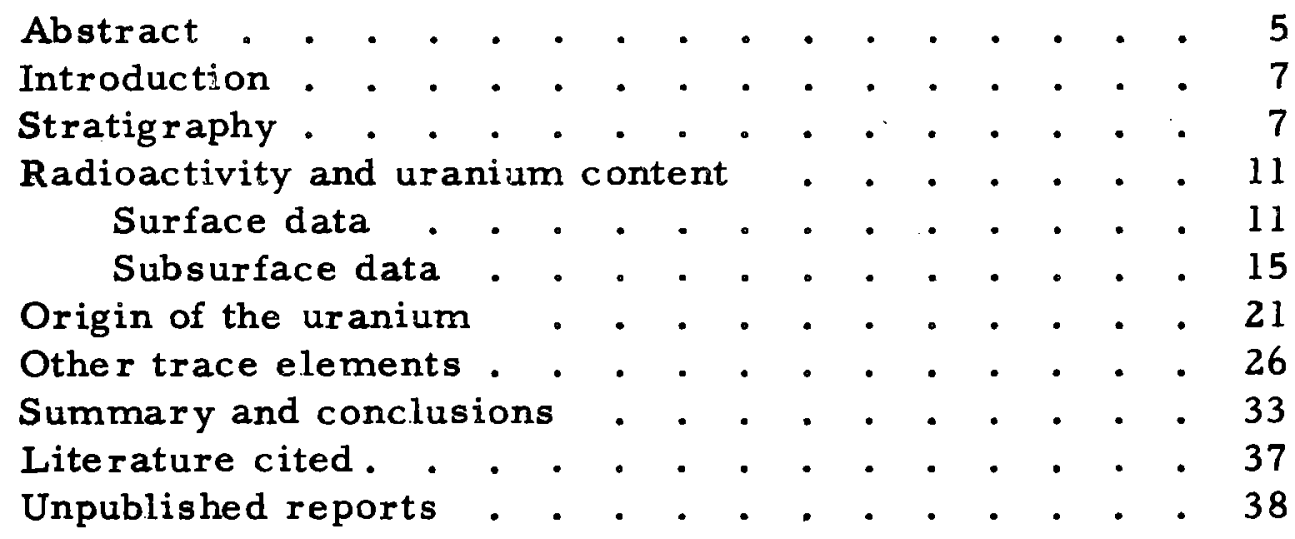

\section{ILLUS TR ATIONS}

Figure 1. Map showing locations of exposures of the lower part of the Pierre shale in Kansas and Colorado. . . . . . . . . . . 12

2. Columnar sections of Sharon Springs member of the Pierre shale in Wallace and Logan Counties, Kansas . . . . . . . . . In envelope

3. Columriar sections of lower part of Pierre shale in Cheyenne, Kiowa, Crowley, and Pueblo Counties, Colorado. . . . . In envelope

4. Columnar sections of lower part of Pierre shale in Las Animas County, Colorado. . In envelope

5. Map of eastern Colorado showing the location of wells used in radioactivity log study of the Pierre shale and Niobrara formation 16

6. Gamma-ray logs of lower part of Pierre shale and upper part of Niobrara formation in eastern Colorado 


\section{TABLES}

$\underline{\text { Page }}$

Table 1. Trace elements composition of some Cre taceous shales from Kansas and Colorado

2. Minimum concentrations of the elements detectable by the semiquantitative spectrographic method, in parts per million. $\mathbf{R e}-$ vised January 13,1954 . . . . . . . 28

3. Description of samples in table $1 . . . \quad 29$ 
RADIOACTIVITY AND URANIUM CONTENT OF THE SHARON SPRINGS MEMBER OF THE PIERRE SHALE AND ASSOCIATED ROCKS IN WESTERN KANSAS AND EASTERN COLORADO

By E. R. Landi s

\section{ABSTRACT}

As a part of the Geological Survey's program of investigating uranium-bearing carbonaceous rocks on behalf of the Division of Raw Materials of the U. S. Atomic Energy Commission, a reconnaissance of the Shar on Springs member of the Pierre shale in western Kansas and eastern Colorado was conducted during 1954.

The Sharon Springs member of the Pierre shale and its lateral equivalents ranges from 155 to about 500 feet in thickness and generally contains about 0.001 percent uranium, but some beds contain larger amounts. A 6-foot thick shale bed in Cheyenne County, Colo., contains about 0.006 percent uranium, a $41 / 2$-foot thick sequence of beds in Crowley County, Colo., is estimated to contain between 0.004 and 0.005 percent uranium, and a $31 / 2$-foot thick sequence of beds in Kiowa County, Colo., contains about 0.004 percent uranium. At several outcrop localíties, sequences of beds as much as $91 / 2$ feet thick contain about 0.003 percent uranium. Data from wells indicate that the $41 / 2$ - foot thick sequence of beds in Crowley County, Colo., may have a lateral extent of at least $51 / 2$ miles. A gamma-ray log of a well in County, Colo., indicates the presence 
of a sequence of beds 66 feet thick which contains 0.005 to 0.010 percent equivalent uranium.

No definite pattern of areal distribution of radioactivity and uranium content in the Sharon Springs is indicated by available da ta. Lateral variation in uranium content of individual beds was not noted in outcrops, which seldom extend more than 150 feet, but subsurface data from gamma-ray logs of wells indicate that both the maximum radioactivity and the thickness of radioactive beds are variable within distances of a few miles. Vertical variation in radioactivity and uranium content of the more radioactive beds is usually abrupt, but in the rocks as a whole the range of uranium content is so small that large variations in content are absent.

In most of the gamma-ray logs examined there is only part of the sequence of rocks comprising the Pierre shale and Niobrara formation that exhibits radioactivity in excess of the average radioactivity of the two formations. Comparison of features of gamma-ray logs of wells in northeastern Colorado suggests that the most radioactive part referred to above is a laterally correlatable sequence of beds.

The stratigraphic position of the radioactive unit relative to the Pierre shale-Niobrara formation contact in oil industry scout reports, as identified from electric $\log s$ of wells, is variable within short distances. This may indicate that some of the Pierre-Niobrara contacts picked from electric logs may not correspond to the boundary that would be selected by examination of the rocks themselves, or may indicate that there is a 
facies relationship between the lowermost part of the Pierre shale and the uppermost part of the Niobrara formation.

\section{INTRODUCTION}

During the field season of 1954, reconnaissance and detailed studies of uranium-bearing black shales of Late Cretaceous age in western Kansas and eastern Colorado were carried on as part of the Geological Survey's program of investigating uranium bearing carbonaceous rocks on behalf of the Division of Raw Materials of the U. S. Atomic Energy Commission. Concurrent investigations were made in western Nebraska (Dunham, R. J., report in preparation) and western South Dakota (Kepferle, R. C., report in preparation). The primary objective of the se studies was to determine the content and distribution of uranium areally and stratigraphically in the Sharon Springs member of the Pierre shale of Late Cretaceous age. Other shales of Late Cretaceous age were also examined.

\section{STRATIGRAPHY}

The Sharon Springs member of the Pierre shale was named by Elias (1931, p. 56) from exposures in Wallace and Logan Counties, Kans. At the type locality, the Sharon Springs consists of 155 feet of flaky, black shale containing an abundance of small fish remains. Dane, Pierce, and Reeside (1937, p. 225) extended the name into eastern Colorado as an equivalent of the "Barren zone" of Gilbert (1897). Searight (1938, p. 137) used the name for the basal member of the Pierre in South Dakota and Condra and Reed 
(1943, p. 17) applied the name to the lowermost part of the Pierre in Nebraska.

In western Kansas the Sharon Springs is overlain by the Weskan member of the Pierre shale, which is the lowest of three units named by Elias (1931, p. 56) in 430 feet of Pierre overlying the Sharon Springs. In eastern Colorado the Sharon Springs is overlain by the "Rusty zone" defined by Gilbert (1897). Dane, Pierce, and Reeside (1937, p. 225) correlated the "Rusty zone" with the three units named by Elias (1931, p. 56) that overlie the Sharon Springs in western Kansas.

The Sharon Springs member is underlain in western Kansas by the Smoky Hill chalk member of the Niobrara formation; in eastern Colorado this is called the Smoky Hill marl member of the Niobrara formation. In the extreme western portion of the report area the Sharon Springs is underlain by the Apishapa shale member of the Niobrara formation. The Apishapa is equivalent to the upper part of the Smoky Hill marl and chalk of eastern Colorado and western Kansas (Cobban and Reeside, 1952, ( $\mathrm{P}$. As seen in the field, the lithologic contact between the Pierre shale and Niobrara formation appears to be conformable and at some localities seems to be gradational. At a few localities, an alternation of dark gray to black calcareous and noncalcareous shales was observed. The contact between the Pierre and the Niobrara is generally placed at the top of the youngest limestone or calcareous shale that is observed in the outcrop. 
The Sharon Springs is predominantly black to dark brown, noncalcareous, organic-rich shale. The shale commonly breaks and weathers into tough, angular, fragments from $1 / 20$ to $1 / 5$ of an inch thick and as much as 2 inches in diameter. Scales, spines, scutes, and other minute remains of fish are so common as to be a definitive feature of the Sharon Springs . Other fossils are so rare, though, that this portion of the Pierre was named the "Barren zone" by Gilbert (1897). Fragments of mollusk shells were noted in several limestone concretions and at one locality in Wallace County, Kans, a few bone fragments, probably of a marine reptile, were found.

Bentonitic clay beds are common in the Sharon Springs and are not restricted to any particular stratigraphic horizon. The beds are commonly less than 6 inches thick and the majority range from $1 / 4$ to 2 inches in thickness. Tourtelot (1956, p. 63) reports bentonite beds almost 20 feet thick in the Sharon Springs near the Black Hills, but none of that magnitude was observed in western Kansas or eastern Colorado. In most places the bentonitic clay beds, which are light gray where unweathered, are represented on weathered surfaces by an intimate mixture of soft, iron-stained, tan to yellow clay, red-brown limonite or hematite, and small, randomly oriented, prismatic crystals of selenite.

Selenite, in the form of rosettes as much as 6 inches in diameter, and as individual crystals, is usually abundant on weathered outcrops. Contact twinning of tabular crystals is common. On several weathered outcrops, 
small veinlets of selenite cut across the bedding planes of the shale. Selenite and rock gypsum commonly encrust the concretions present in the Shar on Springs.

Ellipsoidal concretions consisting of concentrically banded dense gray limestone or shaly limestone are present in the Sharon Springs. Oval calcareous shale concretions, some of which contain rock gypsum or selenite, are also common. The larger and more conspicuous concretions are of the septarian type, in which the dense microcrystalline gray limestone is divided by radiating septaria of calcite and barite. A few of the nonseptarian limestone concretions have an outer crust of tan to light-gray cone-in-cone limestone. Several concretions noted consisted of opposed layers of cone-in-cone limestone without intermediate material. Small tabular concretions consisting of limestone and mudstone are common in parts of the Shar on Springs. A few of the oval iron carbonate concretions that are common in the overlying "Rusty zone" are also present in the Sharon Springs.

Elias (1931, p. 65) assigned a thickness of 155 feet to the Sharon Springs at the type locality in western Kansas, and fifteen miles southwest of the type locality the author measured about 194 feet of Sharon Springs. In eastern Colorado, Dane, Pierce, and Reeside (1937, p. 225) assigned a thickness of about 400 to 500 feet to the Sharon Springs. The author measured a section in Las Animas County, Colo., in which the strata probably assignable to the Sharon Springs are less than 260 feet thick. 
Toartelot (1956, p. 63) states that in South Dakota the Sharon Springs and strata correlated with it range from 17 to 150 feet in thickness, and Condra and Reed (1943, p. 17) assign a thickness of 20 to 80 feet to the Sharon Springs in Nebraska.

There are few distinctive laterally correlatable units in the Sharon Springs, hence the stratigraphic relations between parts of the member in different outcrops is often unknown, or at best, uncertain. Elias (1931, p. 59) subdivided the Sharon Springs into upper and lower parts, differentiating by the abundance of large concretions in the upper part as contrasted to the scarcity and smallness of the concretions in the lower part. Elias (1931, p. 60-61) also indicated that a zone of septarian concretions that occurs in the upper part of the Sharon Springs is laterally correlatable in Wallace and Logan Counties, Kans. Septarian concretions are also present in the Sharon Springs of eastern Coloado (Dane, Pierce, and Reeside, 1937, p. 225). As the concretions are the most resistant constituents of the Sharon Springs, they crop out more often than does the remainder of the member and the tendency is to correlate the zones in which they occur. Several te nuous correlations of septarian concretion zones are indicated on figures 2 and 3 , but some of them may be erroneous.

\section{RADIOAC TIVITY AND UR ANIUM CONTENT}

\section{Surface data}

Figure 1 shows the locations of exposures of the lower part af the Pierre shale in Kansas and Colorado that were examined for radioactivity, 


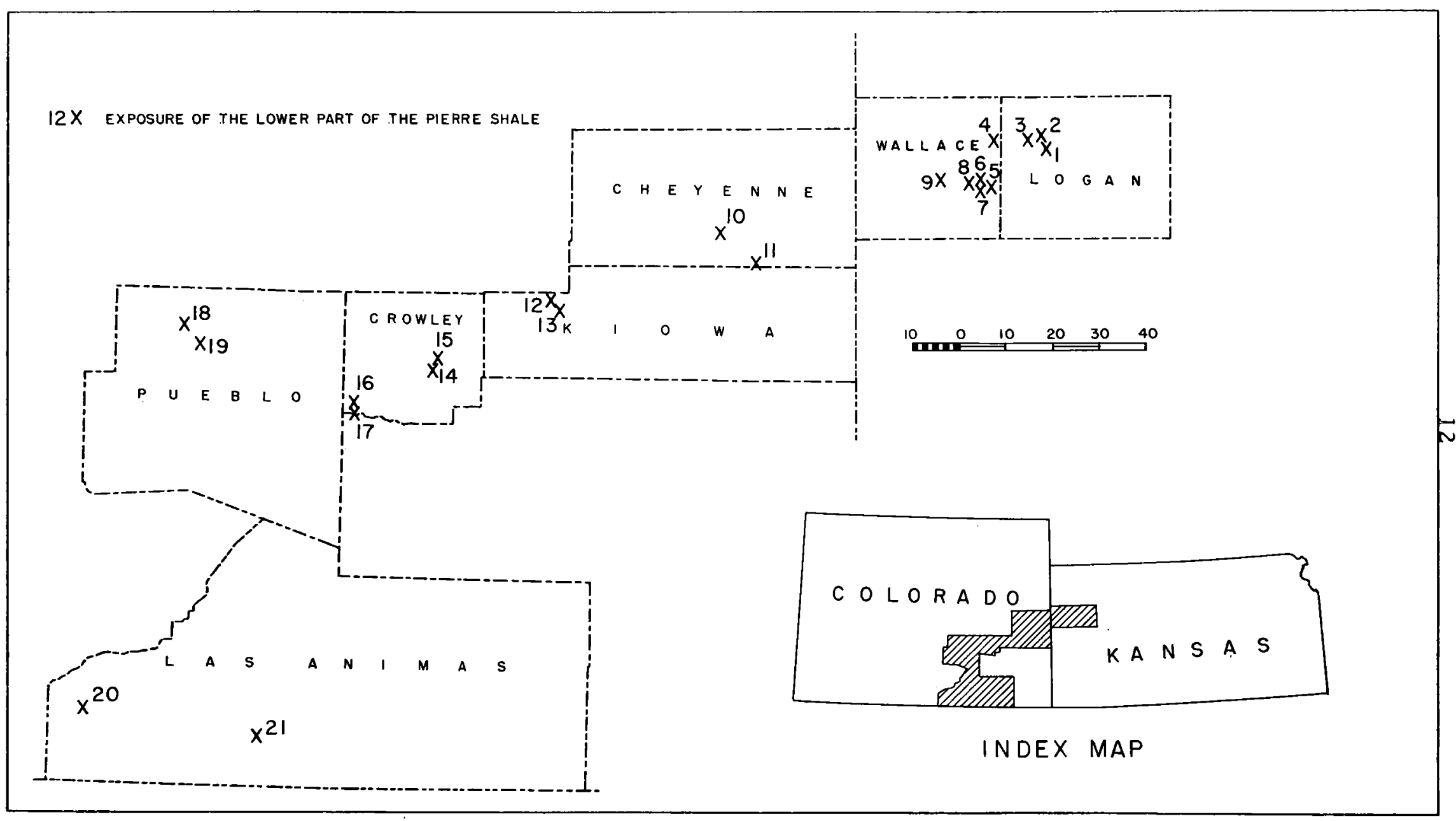

FIGURE I.-MAP SHOWING LOCATIONS OF EXPOSURES OF THE LOWER PART OF THE PIERRE SHALE IN KANSAS AND COLORADO 
measured, and sampled during this investigation. Figures 2, 3, and 4 show columnar sections of the rocks at each of the localities and the equivalent uranium and uranium content of samples collected from the rock units.

Lateral correlation of portions of the Sharon Springs member of the Pierre shale and associated rock units exposed at the various sample localities is rather tenuous, but the probable stratigraphic position of the beds examined at each locality relative to nearby localities is indicated on the columnar sections (figs. 2,3 , and 4 ). No definite laterally correlative stratigraphic sequence was consistently more uraniferous than other portions of the Sharon Springs. The radioactivity and uranium content of individual beds were found to be laterally consistent within the outcrop area of the portions of the Sharon Springs and the adjacent parts of the Pierre which were examined. However, few of the beds were exposed for a distance of over 150 feet at any of the localities.

The lower part of the Pierre shale in the area of this report generally contains 0.003 percent equivalent uranium or less and 0.001 percent uranium or less. Following is a tabulation of all units containing over 0.002 percent uranium and the thickness of each unit. Where thickness and grade figures are separated by "and", units containing 0.002 percent uranium or less are present between the two tabulated units. Uranium contents listed as "estimated" are interpolated from scintillation counter readings of the tabulated unit and scintillation counter readings and analyses of contiguous beds. 
Locality number

(figs. 2, 3, and 4)

2

3

9

10

12

13

15

17

18

20
Thickness

$1 \mathrm{ft} .10 \mathrm{in}$.

$2 \mathrm{ft}$. and

$3 \mathrm{ft}$.

$\mathrm{l} \mathrm{ft}$.

$1 \mathrm{ft}$.

$6 \mathrm{ft}$.

$0 \mathrm{ft} .6$ in.

$1 \mathrm{ft}$.

$2 \mathrm{ft}$.

$4 \mathrm{ft}$.

$1 \mathrm{ft} .4$ in.

$2 \mathrm{ft} .2 \mathrm{in}$.

$1 \mathrm{ft}$.

$3 \mathrm{ft} .1$ in.

$1 \mathrm{ft} .2$ in.

9 ft. 6 in. and

$4 \mathrm{ft} .9$ in.
U content (percent)

0.003

.004

.003

.004

.004

.006

.003 estimated

.006

.003 estimated

.003 to .002

.004 to .003

.005

.007 to .005

equtimated

.003

.003

.003

.003

The disequilibrium between the equivalent uranium cont nt and the uranium content in most of the samples may be due to leaching of uranium from the shale. Tourtelot $(1956$, p. 68) suggested that the equivalent uranium content of weathered shale of the Sharon Springs me mber in South Dakota and Nebraska may be representative of the uranium content of some of the unweathered shale. Lending support to this suggestion is the fact that many samples collected during the present investigation contained exactly as much uranium as equivalent 
uranium. In general, however, the equivalent uraniurn and uranium determinations in the majority of the weathered shale samples reported here differ by 0.001 to 0.002 percent uranium; for example, samples with 0.003 percent equivalent uranium generally contain 0.001 to 0.002 percent uranium. Some of the excess radioactivity indicated by these relationships probably results from potassium in the shale.

\section{Subsurface data}

Figure 5 shows the location of wells in northeastern Colorado for which radioactivity logs were studied. Radioactivity logs normally consist of two curves: the gamma-ray log which records the natural garnma radiation emitted by the rocks through which the well passes; and the ne utron $\log$ which records the gamma radiation emitted by the rocks as a result of neutron bombardment from a source introduced into the hole, the gamma radiation given off by the introduced source and reflected back to the gamma-ray detector, as well as the natural gamma radiation of the rocks. Only the gamma-ray curve indicating the natural radiation of the rocks was considered in the present study. Significant portions of the gamma-ray logs of those wells indicated on figure 5 by a solid circle and a number are shown on figure 6 . The equivalent uranium content of the shale in some of the wells indicated by an $\mathrm{X}$ on figure 5 is taken from gamma-ray logs reported by Tourtelot (1956, fig. 6) and the others are based on the author's examination of $\log s$. 
16

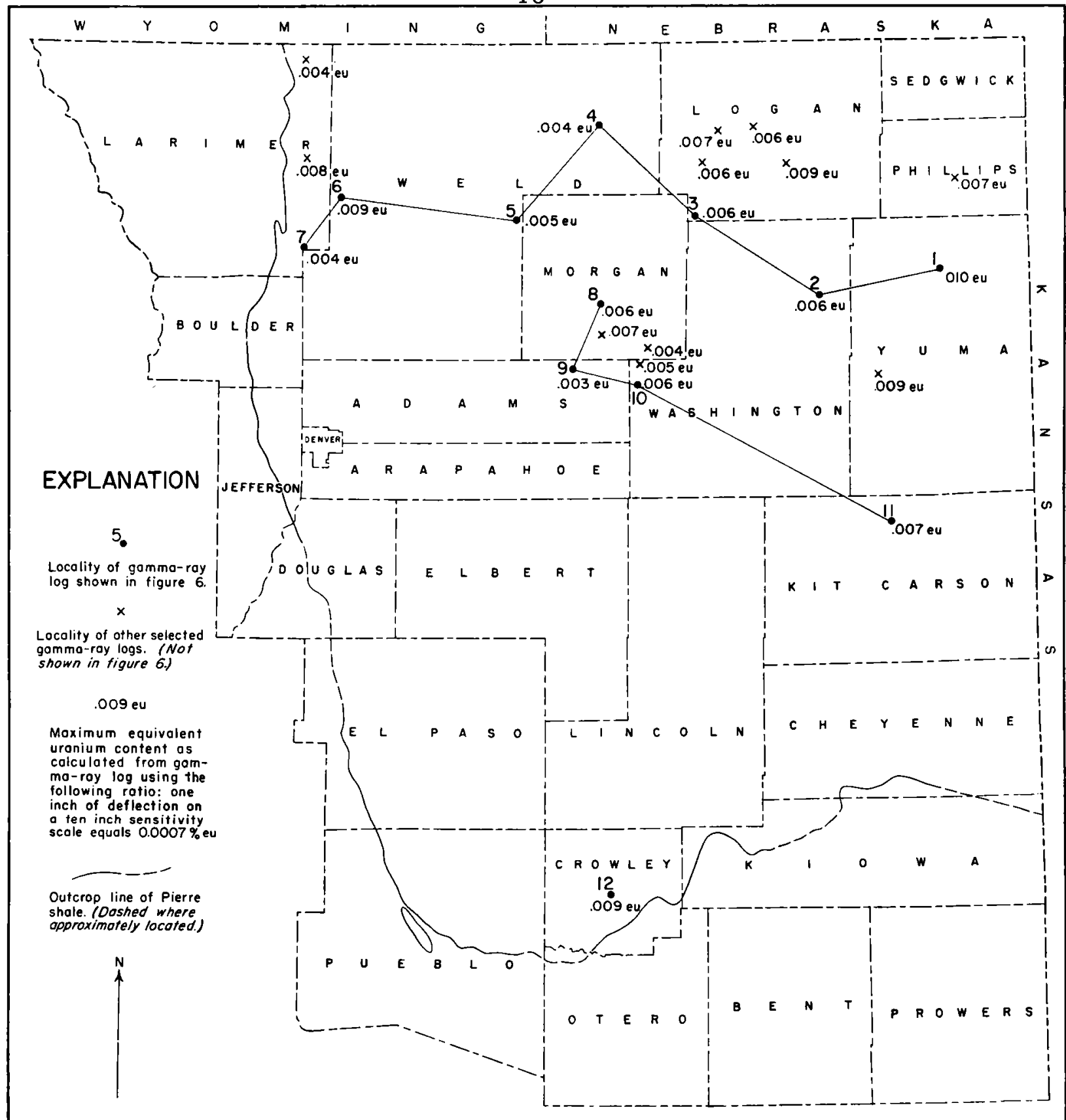

FIGURE 5.-MAP OF EASTERN COLORADO SHOWING THE LOCATION OF WELLS USED IN THE RADIOACTIVITY LOG STUDY OF THE PIERRE SHALE AND NIOBRARA FORMATION 


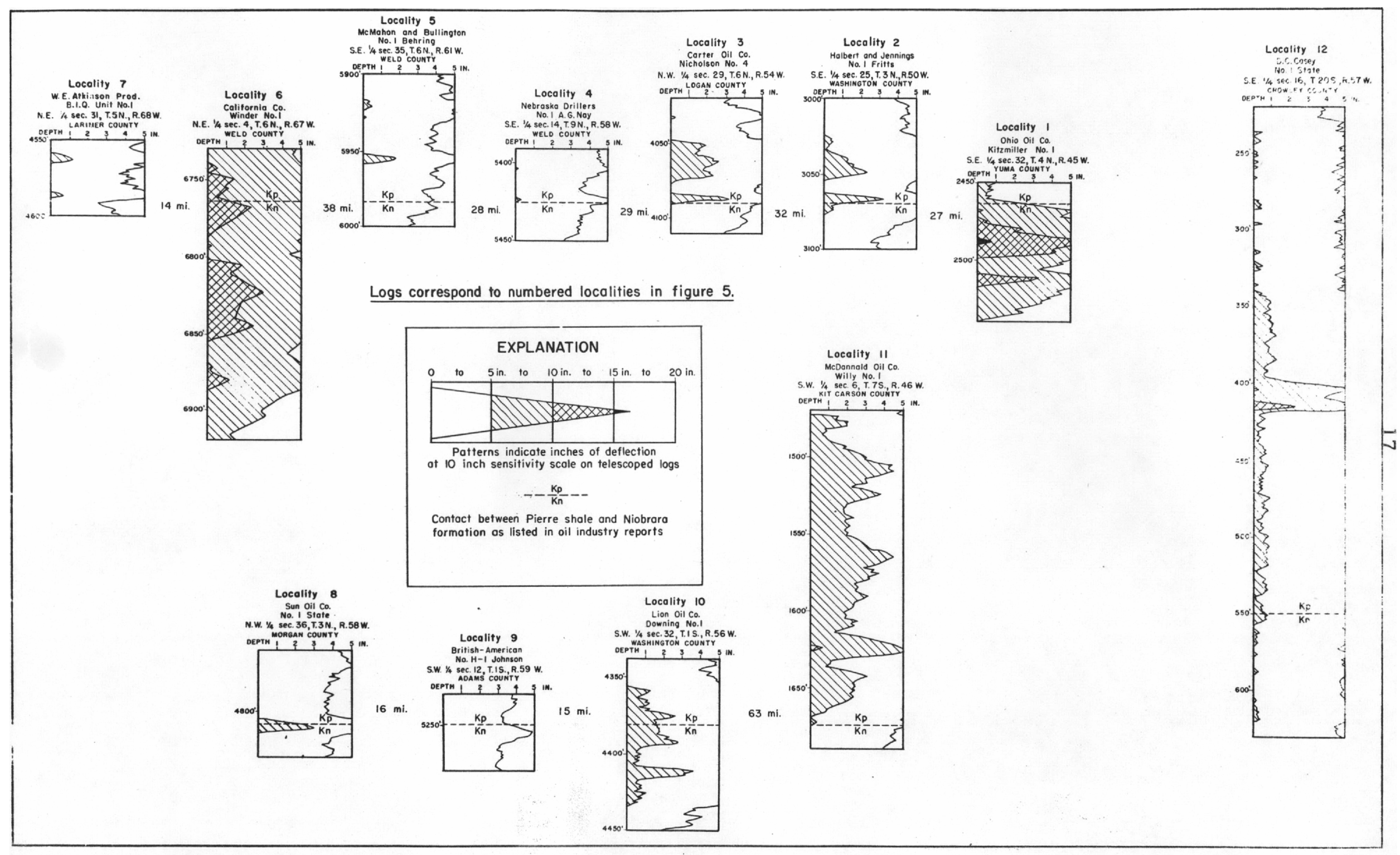

FIGURE 6.- GAMMA-RAY LOGS OF LOWER PART OF PIERRE SHALE AND UPPER PART OF NIOBRARA FORMATION IN EASTERN COLORADO 
The maximum deflection produced by rocks in the Pierre-Niobrara sequence on the gamma-ray logs of the welis on figure 5 is expressed as percentage of equivalent uranium. Gott and Hill (1953, p. 70) found that in the Rangely field of northwestern Colorado, an equivalent uranium content of about 0.0007 percent in core samples of the Weber formation caused a deflection of one inch in the gamma-ray curve at a 10 -inch sensitivity scale. The accuracy of this figure is dependent on many complicating factors, such as the thickness versus the radioactivity of the bed, fluid content of the well, shielding effect of the casing in cased wells, differences in individual instruments, and the rate of movement of the ionization chamber. However, analyses of samples of core fram a well penetrating the Bakken formation in North Dakota were compared with the gamma-ray log of the well, and the Gott and Hill factor was found to be applicable to within an accuracy of 0.001 percent equivalent uranium (Kepferle, R. C., personal communication). The maximum radioactivity shown by the gammaray $\log s$ is at locality 1 , where a sequence of beds about 66 feet thick has an estimated equivalent uranium content of 0.005 to 0.01 percent.

The available data do not indicate any definite areal distribution pattern of radioactivity in the Pierre-Niobrara sequence. A greater number of the wells in the northeastern and eastern parts of the map area fig. 5) exhibit radpactivity near the indicated maximum than do the wells in the central and western portions. However, no definite conclusions on this point can be reached until more subsurface information is available in the southern part of the area in which the Pierre and Niobrara are present. 
The contact between the Pierre shale and the Niobrara formation as shown on figure 6 is as listed in oil industry scout reports. The contact in such reports is generally picked by resistivity and self-potential electric logs without reference to radioactivity logs. In some cases, however, the radioactivity log itself was probably used to pick the contact. For one well (loc. 7) no contact was listed but the portion of the gamma-ray log shown in figure 6 probably includes the Pierre-Niobrara contact. Examination of the electrical log of several wells shown on figure 5 indicates a change in lithology at the depths listed by oil industry reports as being the PierreNiobrara contact. At locality 10 (fig. 6) for instance, the Pierre-Niobrara contact agrees closely with changes in the electrical log curves that may indicate a change in the lithology of the rock. The portions of the gammaray logs shown in figure 6 include the Pierre-Niobrara contact as picked in oil industry scout reports, and the portion of the upper Cretaceous series considered is hereafter referred to as the Pierre-Niobrara sequence.

The gamma-ray logs that were examined show that there is usually only one part of the Pierre-Niobrara sequence that exhibits radioactivity far in excess of the average amount of radioactivity shown by the se forma tions. The gamma-ray logs indicate that the portion which is more radioactive than other parts of those formations ranges in thickness from less than 10 feet to about 150 feet. Many individual peaks of radioactivity with in the more radioactive portion can be correlated in the gamma-ray logs of wells in northeastern Colorado. This suggests that the most radioactive 
portion of the Pierre-Niobraxa sequence in northeastern Colorado is a definite, correlatable sequence of beds.

In nor theastern Colorado the radioactive unit is in all cases located stratigraphically within about 200 feet of the Pierre-Niobrara contact as picked from electric logs. The fact that the radioactive unit varies in stratigraphic position relative to the Pierre-Niobrara contact may indicate that the contact as picked from electric logs does not in all cases correspond to the lithologic boundary that would be picked by examination of the rocks themselves. Another possibility is that the radioactive unit crosses formational boundaries, and there is a facies relationship between the lower most part of the Pierre and the uppermost part of the Niobrara.

The gamma-ray log of the well at locality 12 (fig. 6) is interesting for several reasons. The Pierre-Niobrara contact is listed in scout reports as having been picked approximately by use of rock samples from the well; it is about 130 feet below the base of the most radioactive portion of the Pierre. Examination of outcrops in the same area showed that the most radioactive and uraniferous part of the Pierre is a sandy shale unit that contains iron carbonate concretions and that is located some distance above the top of the Niobrara formation (loc. 15, fig. 3). That the radioactive unit shown in the gamma-ray log at locality 12 (fig. 6) is the same as that observed at the surface is suggested by the presence of a sandy gray shale unit with a limy layer at the top that is present 155 feet above the top of the Niobrara in a well $31 / 2$ miles west of locality 12 and absent in a well about 10 miles north of locality 12 (Hallgarth, W. E, personal communication). 


\section{ORIGIN OF THE URANIUM}

Most of the problems of the origin of the uranium in such black shales as the alum shales of Sweden and the Chattanooga shale of the eastern United States are unsolved. As a group, the uraniferous black shales of the world are sapropelic, highly carbonaceous and bituminous, high in sulfides, noncalcareous, some what phosphatic, and are believed to have accumulated slowly, probably under anaerobic conditions (McKelvey, 1955a, p. 15). The Sharon Springs shale member of the Pierre shale possesses most of the se distinguishing characteristics, though qliantitative data are lacking for some of them.

The uranium in most of the black shales thus far studied has a definite relationship to the organic and bituminous fractions. Bates and others (1953, p. 2), in their study of thin-section autoradiographs of the Chattanooga shale, found that the observable alpha tracks emanated form the interstitial organic mattex and larger organic fragmenss associated with pyrite. The uranium in the uraniferous upper Cambrian shale of Sweden is present in kolm, a black kerogen of obscure origin (McKelvey, 1955b, p. 17). However, Breger and Deul (1955, p. 190) have found that their study of a pyrite-rich sample of the Sharon Springs member from South Dakota indicates that the uranium in the shale may be associated with the mineral fraction.

Conditions producing a low redox potential seem to have been conducive to the formation of most uraniferous black shales, but other physical and chemical factors, such as the rate of accumulation of sedimerts, 
variation in the available supply of uranium, variation in the relative concentration of other elements in solution, and the $\mathrm{pH}$, which affect the precipitation of uranium from aqueous solution, may be as important.

The uranium in the shale may have been deposited syngenetically: that is, adsorbed by organic matter or precipitated from aque ous solution and deposited simultaneously with the associated material of the shale. All or part of the uranium may have a penecontemporaneous origin, that is, adsorbed by organic matter subsequent to deposition and prior to compaction and burial.

At several of the localities at which outcrops of the Sharon Springs were examined, the most uraniferous beds in the exposure were associated with bentonitic clay beds though the clay itself generally contains very little uranium. In South Dakota, the part of the Sharon Springs that contains the most uranium is commonly associated with bentonites (Kepierle, R. C., personal communication). However, many of the portions of the Sharon Springs in Kansas and Colorado which are associated with bentonitic clay beds are no more uraniferous than the remainder of the exposed rocks, and at several localities where parts of the Sharon Springs were found to be most uraniferous, no bentonitic clay beds were apparent. At several exposures, concentrations of uranium believed to be secondary accumulations on the present land surface are intimately related to the presence of bentonitic clays. 
No obvious relationship exists between the syngenetically or penecontemporaneously deposited uranium in the shales and the bentonitic clay beds in the sequence, but Tourtelot (1956, p. 78) suggested that the uranium content of a sea in which volcanic ash was deposited might be increased during the alteration of the ash to bentonite. In this manner the bentonitic clays could have contributed uranium and other metals to other parts of the Sharon Springs without any direct relationship being apparent between the bentonitic clays and the uranium content of adjacent sediments.

Concentrations of uranium believed to be epigenetic in origin are associated with bentonitic clays at localities 12 and 15 (fig. 3). Many ben.. tonitic clay beds and the adjacent shales were sampled and found to contain no more uranium than the exposed rocks as a whole, but at locality 12 (fig. 3) the shale unit exhibiting the greatest radioactivity in the field and containing 0.004 percent equivalent uranium and 0.006 percent uranium is associated with a $1 / 2$-inch bed of altered bentonitic clay that contains 0.005 percent equivalent uranium and 0.006 percent uranium. It is probable that only part of the uranium present in the shale is epigenetic, and the remainder syngenetic or penecontemporane ous but no quantitative estimate is possible. At locality 15 (fig. 3 ) the portion of the measured section containing the most uranium immediately overlies a sandy shale and clay unit that is evidently the lateral equivalent of a 4 -inch bentonitic clay bed present a short distance away. The 4 -inch bentonitic clay bed contains 0.002 percent equivalent uranium and 0.001 percent uranium, but the weathered mixture of clay, limonite or hematite, and selenite that underlies the bentonitic clay contains 0.007 percent equivalent uranium and 0.006 percent 
uranium and the weathered mixture above the clay contains 0.018 percent equivalent uranium and 0.020 percent uranium.

In the exposures examined, a zone of weathered shale and clay is generally present where the bentonitic clay beds crop out. In these zones, which range in thickness from half an inch or less to about three feet, the bentonitic clay is usually almost totally altered and replaced by a mixture of soft clay, limonite or hematite, and selenite; the adjacent strata are coated and permeated with iron oxide and selenite. A possible explanation of the relationship of the bentonitic clay to the epigenetic concentrations of uranium is that the clay, by virtue of its impermeability, creates a local perched water table that controls the direction of flow of water in the rocks superjacent to the bentonitic clay beds. At locality 15 (fig. 3) the re is a marked differential in uranium content between the weathered mixture above the clay bed and the weathered mixture below the clay bed. The sampling procedure at locality 12 (fig. 3 ) does not indicate whether or not this differential also exists at that locality.

The persistence of iron oxide in the more radioactive units suggests that the concentration of uranium in these units is at least partially due to the iron. The mechanism may be that suggested by Lovering $(1955$, p. 186) who concluded that when acid sulfate waters carrying uranyl sulfate and ferric sulfate are neutralized, the ferric sulfate hydrolizes to form colloidal ferric oxide hydrate which adsorbs the uranyl ion, and later expels it to form secondary uranium minerals when the ferric oxide hydrate crysstallizes to form goethite. 
The uranium may also be present in the selenite. A sample of a selenite veinlet at locality 3 (fig. 2 ) contained 0.001 percent equivalent uranium and 0.002 percent uranium. Bain $(1953$, p. 207) has shown that calcium can precipitate uranium from uranyl sulfate solution by appropriating the sulfate ion. Substitution of uranium for calcium may occur, as their respective ionic radii are similar, but it is unlikely because of the difference in ionic charge (McKelvey and others, 1955, p. 9).

The presence of the bentonitic clay beds and zones of weathered shale adjacent to them does not insure the presence of uranium, however, because many of the zones and clay beds of this type that were examined and sampled contained no more uranium than did the adjacent rocks as a whole. Other factors which appear especially important in concentrating uranium on weathered outcrops are the amount of uranium available in aqueous solutions for concentration, and the preservation of the uraniurn from subsequent leaching after it is concentrated. The availability of uranium is a function of the uranium content of the unweathered shale and the preservation of the uranium is a function of the mechanisms of concentration, and possibly of the topographic setting.

Some other uranium occurrences are believed to be partly or totally epigenetic in nature. At locality 2 (fig. 2) uranium is concentrated in one portion of a limestone concretion, and at locality 3 (fig. 2) the outer crust of a concretion contains twice as much uranium as does its center. At locality 2 the uranium is evidently concentrated in the part of the concretion that contains the most organic material. Studies on the Colorado Plateau and other areas indicate that carbonaceous and organic material may assist 
in the precipitation of uranium from solution by the creation of a localized reducing environment. This mechanism may be responsible for the concentration at locality 2. At locality 3 the calcareous shale that makes up the interior of a concretion contains 0.002 percent equivalent uranium and 0.002 percent uranium that is probably of syngenetic origin. The outer, cone-incone, limestone crust of the concretion contains 0.002 percent equivalent uranium and 0.004 percent uranium. The crust must have formed after the deposition of the enclosing sediments, but whether the uranium was emplaced in the crust at the time of formation or has been subsequently concentrated in it, is unknown.

\section{OTHER TRACE ELEMENTS}

Table 1 shows the results of semiquantitative spectrographic analyses of samples of the Sharon Springs member of the Pierre shale and other shales of Cretaceous age collected in western Kansas and eastern Colorado. Table 2 lists the standard sensitivities for the elements. Table 3 describes the samples shown in table 1. The chemical, radioactivity, and spectrographic analyses were made by the Washington laboratory of the U. S. Geological Survey.

The sample analyses shown in table 1 include a black shale from the Cheyenne sandstone member of the Purgatoire formation, a black shale from the Blue Hill shale member of the Carlile shale, a calcareous shale from the uppermost part of the Smoky Hill chalk member of the Niobrara formation, and twelve samples from various horizons in the Sharon Springs me mber of the Pierre shale. 
Table 1.--Trace elements composition of some Cretaceous shales from Kansas and Colorado. 1/

¿ample number Be B $\mathrm{Na}$ Mg Al Si K Ca Sc Ti V Cr Mn Fe Co Ni Cu Zn Ga Sr Y Zr Mo Ag Sn Ba La Yb Pb Ce Nd Se $3 /$ a

As $\underline{3} / \mathrm{U} \underline{3} /$ $\begin{array}{rrrrrrrrrrrrrr}139759 & - & 5 & 7 & 7 & 11 & 11 & 8 & 7 & 2 & 7 & 3 & 4 & 5 \\ 139758 & - & 5 & 9 & 9 & 10 & 11 & 9 & 7 & 3 & 7 & 4 & 5 & 5 \\ 139726 & - & 5 & 7 & 8 & 9 & 9 & 8 & 11 & 3 & 6 & 5 & 5 & 5 \\ 139727 & - & 5 & 7 & 9 & 10 & 11 & 9 & 9 & 3 & 7 & 5 & 7 & 5 \\ 139732 & - & 5 & 7 & 7 & 11 & 11 & 9 & 9 & 3 & 7 & 4 & 3 & 5 \\ 139733 & - & 5 & 8 & 7 & 11 & 11 & 9 & 9 & 3 & 7 & 5 & 3 & 4 \\ 139734 & - & 5 & 8 & 7 & 10 & 11 & 9 & 9 & 2 & 7 & 5 & 3 & 4 \\ 139754 & - & 5 & 8 & 7 & 10 & 11 & 9 & 9 & 3 & 7 & 5 & 5 & 4 \\ 139755 & - & 5 & 7 & 7 & 10 & 11 & 9 & 7 & 3 & 7 & 5 & 5 & 5 \\ 139756 & - & 5 & 9 & 9 & 10 & 11 & 9 & 7 & 3 & 7 & 5 & 5 & 5 \\ 136757 & - & 5 & 9 & 9 & 10 & 11 & 9 & 9 & 3 & 7 & 5 & 5 & 5 \\ 139760 & 1 & 5 & 9 & 9 & 10 & 11 & 9 & 9 & 3 & 7 & 4 & 4 & 6 \\ 139761 & 1 & 5 & 9 & 9 & 10 & 11 & 9 & 9 & 3 & 7 & 4 & 5 & 5 \\ 139762 & 1 & 5 & 9 & 8 & 10 & 11 & 9 & 8 & 3 & 7 & 5 & 5 & 5 \\ 139763 & 1 & 5 & 9 & 9 & 10 & 11 & 9 & 9 & 3 & 7 & 5 & 5 & 5\end{array}$

\section{Parts per million Code}

\begin{tabular}{|c|c|c|}
\hline \multicolumn{2}{|c|}{ More than 100,000} & 11 \\
\hline 50,000 & $-100,000$ & 10 \\
\hline 10,000 & $-\quad 50,000$ & 9 \\
\hline 5,000 & 10,000 & 8 \\
\hline 1,000 & 5,000 & 7 \\
\hline 500 & 1,000 & 6 \\
\hline 100 & 500 & 5 \\
\hline 50 & 100 & 4 \\
\hline 10 & 50 & 3 \\
\hline 5 & 10 & 2 \\
\hline 1 & - & 1 \\
\hline
\end{tabular}

$\begin{array}{lll}9 & 3 & 4 \\ 9 & 3 & 3 \\ 9 & 3 & 5 \\ 9 & 3 & 5 \\ 9 & 3 & 5 \\ 9 & - & 4 \\ 9 & - & 4 \\ 9 & - & 3 \\ 9 & - & 3 \\ 9 & - & 3 \\ 9 & 3 & 5 \\ 9 & 3 & 4 \\ 9 & 3 & 4 \\ 9 & - & 3 \\ 9 & 3 & 5\end{array}$

5

$\begin{array}{llllll}4 & 5 & 3 & 5 & - & - \\ 3 & 5 & 3 & 5 & - & - \\ 3 & 5 & 3 & 3 & 4 & - \\ 3 & 5 & 3 & 3 & 3 & - \\ 4 & 5 & 3 & 3 & 4 & - \\ 4 & 6 & 3 & 3 & 4 & 1 \\ 4 & 5 & 3 & 3 & 5 & - \\ 3 & 6 & 3 & 3 & 5 & - \\ 3 & 5 & 3 & 4 & 3 & - \\ 3 & 5 & 3 & 4 & 5 & - \\ 3 & 6 & 3 & 4 & 3 & - \\ 3 & 5 & 3 & 4 & - & - \\ 3 & 5 & 3 & 4 & - & - \\ 3 & 5 & 3 & 5 & 4 & - \\ 3 & 5 & 3 & 5 & 3 & -\end{array}$

$2 /$

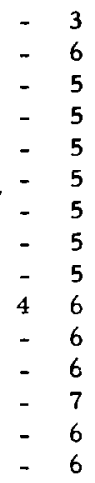

$2(<.001)$

$2(<.001) \quad 3(.002)$

$3(.005) \quad 4(.007)$

$3(.002)$

$2(.001)$

$3(.005)$

$3(.002)$

$2(.001)$

$2(.001)$

$3(.002)$

$3(.003)$

2(<.001)

$2(<.001)$

$2(.001)$

$2(.001)$
1/ Analysts, M. Delevaux, J. Goode, B. A. McCall, P. Moore, and C. Annell, U. S. Geological Survey.

2/ 0.1 to $0.5 \mathrm{ppm} \mathrm{Ag}$ present.

3/ Selenium, arsenic, and uranium contents were determined chemically. The figures shown in the table in parentheses are percent.

- Indicates that the element, if present, is in quantities less than the minimum detectable concentrations listed in Table 2. Other elements listed in Table 2 were also looked for but are not present in detectable amounts. 
Table 2. --Minimum concentrations of the elements detectable by the semiquantitative spectrographic method, in parts per million. Revised January 13, 1954. Washington laboratory, U. S. Geological Survey.

Minimum

Element concentration

$\begin{array}{lc}\mathrm{Ag} & 0.1 \\ \mathrm{Al} & 1 \\ \mathrm{As} & 100 \\ \mathrm{Au} & 10 \\ \mathrm{~B} & 50 \\ \mathrm{Ba} & 10 \\ \mathrm{Be} & 0.5 \\ \mathrm{Bi} & 50 \\ \mathrm{Ca} & 100 \\ \mathrm{Cd} & 50 \\ \mathrm{Ce} & 300 \\ \mathrm{Co} & 80 \\ \mathrm{Cr} & 6 \\ \mathrm{Cs} & 8,000 \\ \mathrm{Cu} & 0.5 \\ \mathrm{Dy} & 60 \\ \mathrm{Eu} & 30 \\ \mathrm{Er} & 30 \\ \mathrm{~F} & 800 \\ \mathrm{Fe} & 8 \\ \mathrm{Ga} & 40 \\ \mathrm{Gd} & 60 \\ \mathrm{Ge} & 10\end{array}$

\section{Minimum} concentration Element
Minimum concentration
Hf

$\mathrm{Hg}$

Ho

In

Ir

K

La

Li

Lu

Mg

Mo

$\mathrm{Mn}$

$\mathrm{Nb}$

$\mathrm{Na}$

$\mathrm{Nd}$

$\mathrm{Ni}$

Os

$P$

$\mathrm{Pb}$

Pd

Pr

$P \mathfrak{t}$

$\mathrm{Rb}$
300

800

10

4

300

3,000

30

400

50

0.3

5

7

10

100

60

50

1,000

700

10

30

100

30

70,000
$\mathrm{Re}$

$\mathrm{Rh}$

$\mathrm{Ru}$

$\mathrm{Sb}$

Sc

$\mathrm{Si}$

$\mathrm{Sm}$

Sn

Sr

Ta

$\mathrm{Tb}$

$\mathrm{Te}$

Th

Ti

Tl

$\mathrm{Tm}$

U

V

W

$\mathrm{Y}$

$\mathrm{Yb}$

$\mathrm{Zn}$

Zr
400

40

80

100

10

50

80

40.

10

1,000

100

800

800

5

400

10

800

10

700

30 
Table 3.--Description of samples in table 1.

Sample no. $\quad$ Description

139759 Black shale six inches thick separating sandstone units of the Cheyenne sandstone me mber of the Purgatoire formation.

Sec. 34, T. 28 S., R. 51 W., Las Animas County, Colo.

$139758 \quad$ Black shale representative of uppermost 50 feet of Blue Hill shale member of the Carlile shale. Sec. 34, T. 23 S., R. 55 W., Otero County, Colo.

139726

Gray calcareous shale from uppermost ten feet of Smoky Hill chalk member of Niobrara formation. Collected on same exposure as 139727 .

Sec. 33, T. 12 S., R. 36 W., Logan County, Kans.

139727 Black shale from lowermost ten feet of Sharon Springs member of Pierre shale. Collected on same exposure as 139726 .

Sec. 33, T. 12 S., R. 36 W., Logan County, Kans.

139732 B.lack shale representative of four feet of shale underlying lowest septarian concretion zone in Sharon Springs member at Mc Allaster Buttes.

Sec. 13, T. 12 S., R. 37 W., Logan County, Kans.

139733 Medium gray shale from Sharon Springs member, repre sentative of one foot unit six feet above upper concretion horizon at McAllaster Buttes.

Sec. 13, T. 12 S., R. 37 W., Logan County, Kans.

139734 Black shale from Sharon Springs member, representative of two foot unit at upper concretion horizon, Mc Allaster Buttes.

Sec. 13, T. 12 S., R. 37 W., Logan County, Kans.

139754 Brown weathered shale from Sharon Springs member. Representative of six feet of shale below septarian concretion horizon.

Sec. 29, T. 15 S., R. 46 W., Cheyenne County, Colo.

139755 Brown weathered shale from Shar on Springs member. Represents $11 / 2$ feet of section. Sec. 26, T. 18 S., R. 52 W., Kiowa County, Colo. 
Table 3.--Description of samples in table 1.- Continued

Sample no. Description

139756

Dark gray iron-stained shale from Sharon Springs member. Represents $12 / 3$ feet of section.

Sec. 30, T. 20 S., R. 56 W., Crowley County, Colo.

139757

Black shale from Sharon Springs member, in upper 100 feet, represents 3 feet 1 inch of section.

Sec. 4, T. 22 S., R. 59 W. , Crowley County, Colo.

$139760 \quad$ Black shale adjacent to igneous dike. Sharon Springs member.

Sec. 30, T. 32 S., R. 68 W., Las Animas County, Colo.

$139761 \quad$ Black shale from Sharon Springs member. Sec. 29, T. 33 S., R. 62 W., Las Animas County, Colo.

139762

Black shale from Sharon Springs member.

Sec. 8, T. 19 S., R. 65 W., Pueblo County, Colo.

139763

Black to dark brown shale from Shar on Spring 6 me mber.

Sec. 35, T. 19 S., R. 65 W., Pueblo County, Colo. 
The sample of shale from the Purgatoire formation (139759) contains less barium than any other sample. In general, the trace element constitution of the sample is similar to the samples of the Shar on Springs member except that it contains less scandium, vanadium, and barium, and more zirconium, than do most of the Sharon Springs samples.

Although the trace element composition of the Blue Hill shale sample (139758) is in general very similar to the analyses of the Sharon Springs, several striking differences are apparent in the comparative contents of the rare earth elements. Three of the se elements, cerium, lanthanum, and neodymium, are present in the semiquantitative range from 100 to 500 ppm, whereas these elements were not detected in any of the other samples. The relative concentration of lanthanum and neodymium in the Blue Hill shale sample (139758) is particularly noteworthy because the minimum concentrations detectable by the spectrog raphic method are $30 \mathrm{ppm}$ lanthanum and $60 \mathrm{ppm}$ neodymium. Thus the sample contains more than 3 times as much lanthanum and more than twice as much neodymium as do any of the other samples. Cerium, lanthanum, and neodymium are closely related in chemical properties (Goldschmidt, 1954, p. 310), and their association is not surprising. The other elements of the cerium earth elements group, praseodymium and samarium, are probably also present but in quantities less than the minimum detectable concentration by semiquantitative spectrographic analysis. 
The sample of the Smoky Hill chalk member of the Niobrara formation (139726) is distinct from all of the other samples by virtue of the larger calcium content and smaller silic on and aluminum contents. In addition to these differences the sample contains more zinc, selenium, and arsenic than most of the other samples although the contrast in selenium content is not great. Compared to the Sharon Springs samples in general, the Smoky Hill sample (139726) contains less sodium, magnesium, potassium, titanium, and copper. The arsenic and selenium contents of this sample are as high or higher than the contents of the se elements in any of the Sharon Springs samples, some of which contain three times as much uranium.

Several areal distribution patterns of specific elements are indicated in the Sharon Springs samples. Those samples from the Sharon Springs along the Front Range of Colorado (139760, 139761, 139762, 139763) contain more beryllium than the other samples and also tend to contain more sodium, magnesium, zirconium, and barium. The samples from the McAllaster Buttes locality (139732, 139733, 139734) all contain more gallium and less chromium than samples from any other locality. The se elemental variations may be largely due to differences in the detrital mineral content of the shale.

Sample 139756 contains more than twice as much lead as does any other sample. This increased concentration may indicate that at time of deposition reducing conditions were greater than was the case at the time of deposition of the other rocks from which samples were 
collected, or it may indicate an increased available supply of lead at the time of deposition.

No definite affinity between uranium and any other element or elements is apparent from the spectrographic analyses. However, in a general way and with seeming exceptions, the molybdenum and arsenic contents are greater in the samples containing the larger amounts of uranium. An even less definite relationship of the same type may exist between selenium content and uranium content.

\section{SUMMARY AND CONCLUSIONS}

The Sharon Springs member of the Pierre shale in western Kansas and eastern Colorado is slightly uraniferous at all of the localities at which it was examined and sampled. Surface examination and sampling does not indicate the presence of any widespread zone that is more uraniferous regionally than the remainder of the member. At any locality, the more uraniferous beds of the exposed shale vary little within the outcrop area, but individual beds were seldom exposed for distances exceeding 150 feet. Closely spaced samples indicate that the yertical variations in uranium content can be very sharp, especially adjacent to the more uraniferous portions, but the range of uranium contents in the shale is not usually large.

Surface and substurface data suggest that the most radioactive paraf the Pierre in Crowley County, Colo. is persistently so for a 
distance of at least $51 / 2$ miles (loc. 15, fig. 3 , and loc. 12, fig. 6). The gamma-ray logs of wells penetrating the Pierre shale and Niobrara formation in northeastern Colorado indicate that the maximum radioactivity, thickness, and the stratigraphic position of the most radioactive parts of the Pierre-Niobrara sequence relative to the Pierre-Niobrara contact picked on electric logs are variable in distances of a few miles. In most of the gamma-ray logs studied, only part of the sequence exhibits radioactivity in excess of the average radioactivity of the remainder of the formations. The fact that individual features of this most radioactive part can be correlated in the gamma-ray logs of wells in northeastern Colorado suggests that the most radioactive part is a laterally correlatable sequence of beds. If the Pierre-Niobrara contacts picked by use of electric logs are accurate placements of the lithologic boundary between the Pierre and Niobrara, the radioactive unit crosses formational boundaries and there may be a facies relationship between the Pierre and Niobrara, Another possibility is that some of the contacts picked from electric $\log s$ do not correspond to the lithologic boundary between the Pierre shale and the Niobrara formation that would be picked by examination of the rocks themselves.

The Sharon Springs member of the Pierre shale and the other portions of the lower part of the Pierre, that were examined, contain an estimated average of about 0.001 percent uranium. The most uraniferous sequence of beds of any appreciable thickness is 6 feet thick and 
contains about 0.006 percent uranium, as indicated by one sample (loc. 10 , p. $14 l_{0}:$ Another sequence of beds $41 / 2$ feet thick contains 0.004 to 0.005 percent uranium (loc. 15, p. 14) and one $31 / 2$ feet thick is estimated to contain about 0.004 percent uranium (loc. 12, p. 14). At several localities sequences of beds up to $91 / 2$ feet thick contain about 0.003 percent uranium. (See p. 14.) The maximum radioactivity observed in gammaray $\log s$ is in Yuma County, Colo., where a 66 -foot sequence of beds exhibits radioactivity from 0.005 percent equivalent uranium to a maximum of 0.010 percent equivalent uranium (loc. 1 , fig. 6).

The uranium contained in uraniferous black marine shale is generally believed to have a syngenetic or penecontemporaneous origin. Inas much as this report contributes no data to the contrary, it is presumed that the uranium in the Sharon Springs member of the Pierre shale has a similar origin.

Several occurrences of uranium believed to be epigenetic in origin were located, but the magnitude of the concentrations is very small. In Crowley County, Colo., a 2 -inch thick bed of mixed bentonitic clay, hematite or limonite, and selenite, contained 0.020 percent uranium; and in Logan County, Kans., an organic-rich part of a limestone concretion contained 0.016 percent uranium. Several other occurrences in which part or all of the uranium is believed to be epigenetic contain as much as 0.006 percent uranium. At two localities at which uranium of papsible epigenetic origin is present, the occurrences are believed to be related 
to weathering effects and the presence of bentonitic clay beds, although other factors such as the amount of uranium in aqueous solution that was local ly available for concentration also probably had a direct relationship to the concentrations.

No definite relationship is apparent between uranium and any other element in the semiquantitative spectrographic analyses, but in a general way, and with exceptions, the samples containing the larger amounts of 4 ranium also contain larger amounts of molybdenum, arsenic, and selepium. 


\section{LITERATURE CITED}

Bain, G. W., 1953, Experimental sirnulation of Plateautype uranium deposits: RMO-44, 210 p. , U. S. Atomic Energy Commission, Tech. Inf. Service, Oak Ridge.

Bates, T. F., Wright, H. D., Camilli, E., Nelson, B., Strahl, E., Weiser, L., 1953, An investigation of the mineralogy, petrog raphy, and paleobotany of uranium-bearing shales and lignites, Quarterly Progress Report, October 1, 1952, to December 31, 1952: The Pennsylvania State College, School of Mineral Industries, Division of Mine ralogy, NYO-3358, Part I, U. S. Atomic Energy Comm. Contract No. At(30-1)-1202, Project No. E-32, p. 2 .

Breger, I. A., and Deul, Maurice, 1955, Geochemistry of uraniumbearing carbonaceous rocks in Geologic investigations of radioactive deposits, semiannual progress report, December 1, 1954 to May 31, 1955: U. S. Geol. Survey Trace Elements Inv. Rept. 540, p. 183-190, U. S. Atomic Energy Comm., Tech. Inf. Service, Oak Ridge.

Cobban, W. A., and Reeside, J. B., Jr., 1952, Correlation of the Cretaceous formations of the western interior of the United States: Geol. Soc. America Bull., v. 63, p. 1011-1044.

Condra, G. E., and Reed, E. C., 1943, The geological section of Nebraska: Nebraska Geol. Survey Bull. 14, 82 p.

Dane, C. H., Pierce, W. G., and Reeside, J. B., Jr., 1937, The stratigraphy of the Upper Cretaceous rocks north of the Arkansas River in eastern Colorado: U. S. Geol. Survey Prof. Paper 186-K, p. 207-232.

Elias, M. K., 1931, The geology of Wallace County, Kansas: State Geol. Survey of Kansas Bull. 18, 254 p.

Gilbert, G. K., 1897, Pueblo Quadrangle: U. S. Geol. Survey Geol. Atlas, Pueblo, Colo. folio (no. 36), 9 p.

Goldschmidt, V. M. , 1954, Geochemistry: Oxford University Press, London, $730 \mathrm{p}$.

Gott, G. B., and Hill, J. W., 1953, Radioactivity in some oil fields of southeastern Kansas: U. S. Geol. Survey Bull. 988E, p. 69-122. 
Hills, R. C., 1899, Description of the Elmorolquadrangle: U. S. Geol. Survey Geol. Atlas 58, 5 p.

Lovering, T. G., 1955, Progress in radioactive iron oxides investigations: Econ. Geology, v. 50, no. 2, p. 186-195.

McKelvey, V. E., 1955a, Search for uranium in the United States: U.S. Geol. Survey Bull. 1030-A, 64 p.

Searight, W. V., 1938, The microfauna of the Sully member of the Pierre: Iowa Acad. Sci. Proc., v. 45, p. 135-137.

Tourtelot, H. A., 1956, Radioactivity and uranium content of some Cretaceous shales, Central Great Plains: Bull. Amer. Assoc. Petrol. Geol., vol. 40, no. 1, p. 62-83.

\section{UNPUBLISHED REPOR TS}

McKelvey, V. E., 1955b, Uranium in the Upper Cambrian black shale of Sweden: U. S. Geol. Survey Trace Elements Inv. Rept. 495, $19 \mathrm{p}$.

McKelvey, V. E., Everhart, D. L., and Garreis, R. M., 1955, Origin of uranium deposits: U. S. Geol. Survey Trace Elements Inv. Rept. 504, 102 p. 


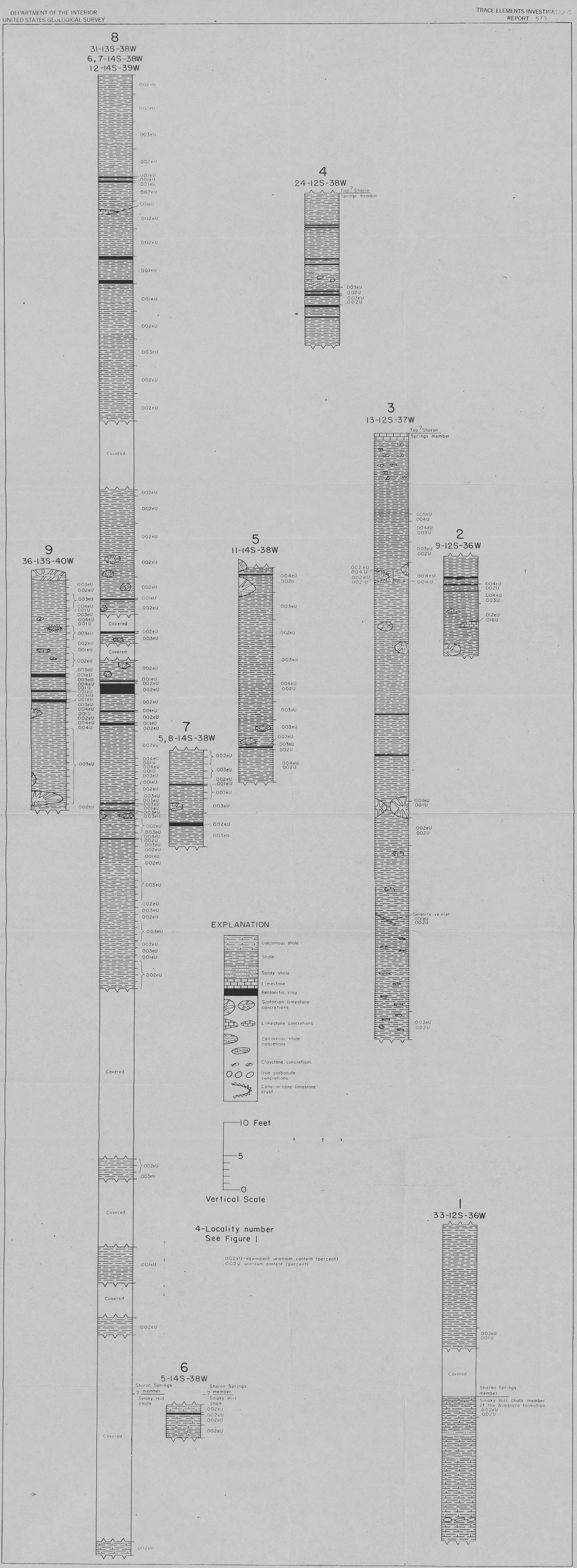

FIGURE 2-GRAPHIC SECTIONS OF SHARON SPRINGS MEMBER OF PIERRE SHALE IN WALLACE AND LOGAN COUNTIES, KANSAS. 


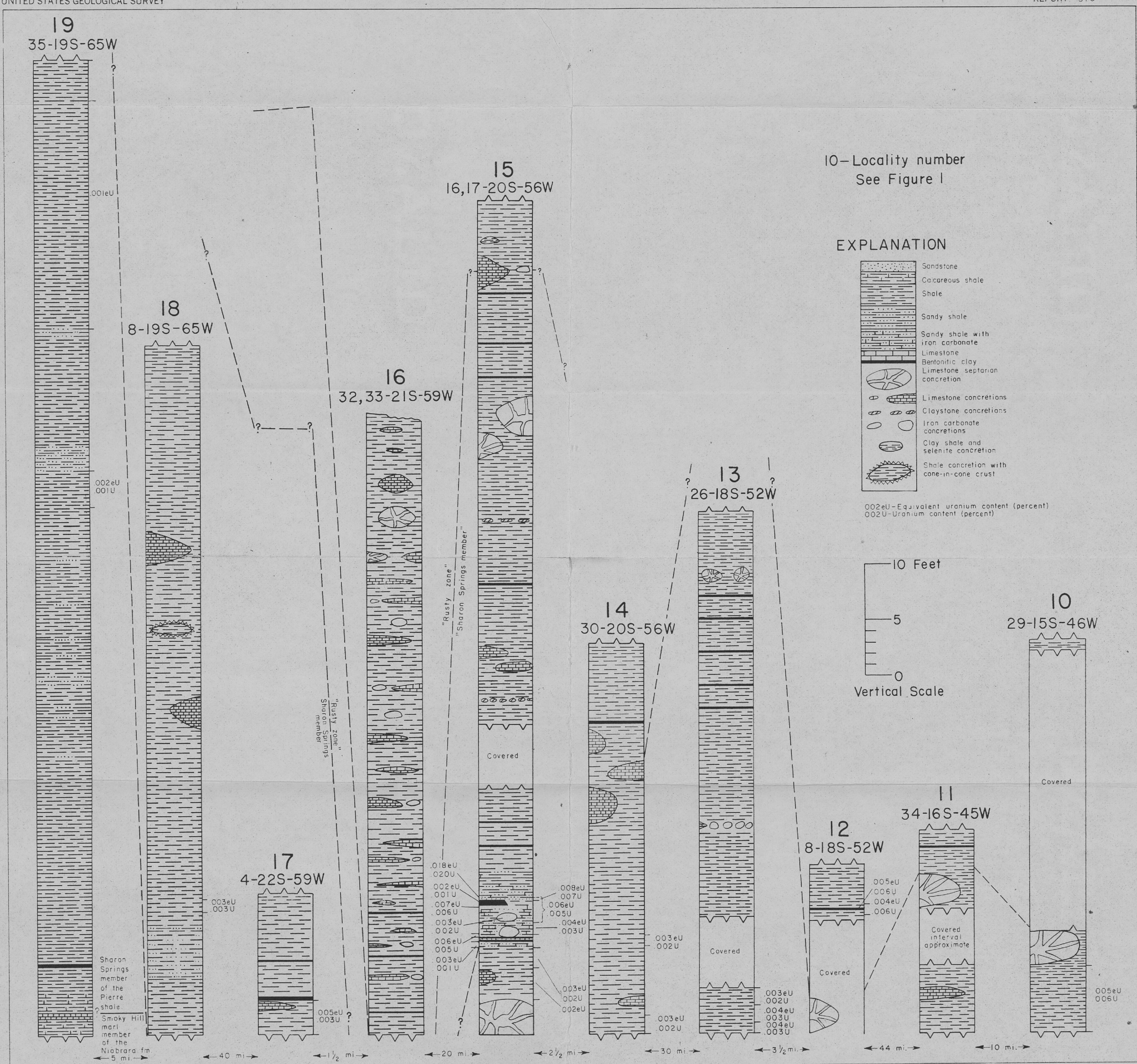

FIGURE 3-GRAPHIC SECTIONS OF LOWER PART OF PIERRE SHALE IN CHEYENNE, KIOWA, CROWLEY, AND PUEBLO COUNTIES, COLORADO 
21

$20,22,28,29-33 S-62 W$

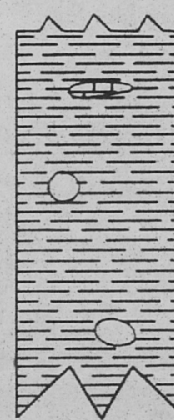

$50^{\prime}$ some
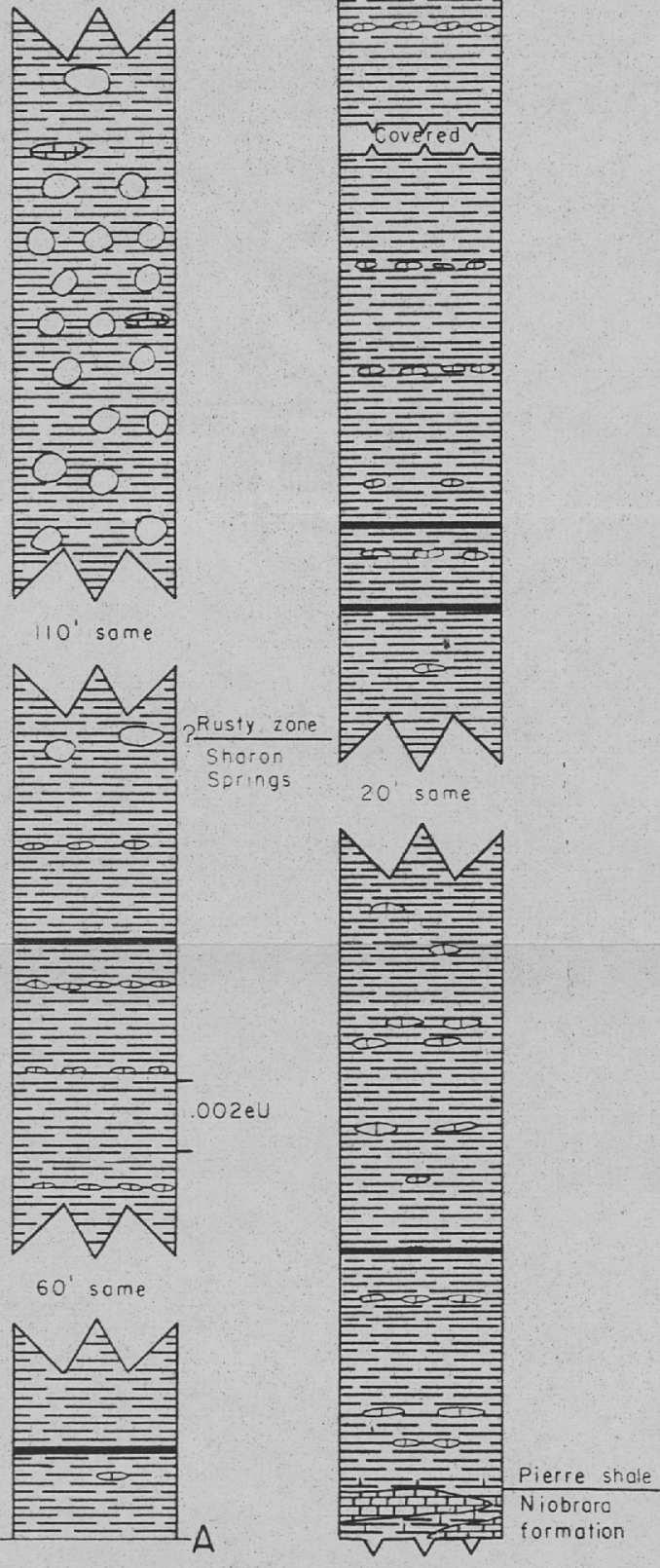

$60^{\circ}$ some

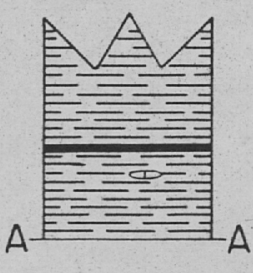

20

$30-32 S-68 W$
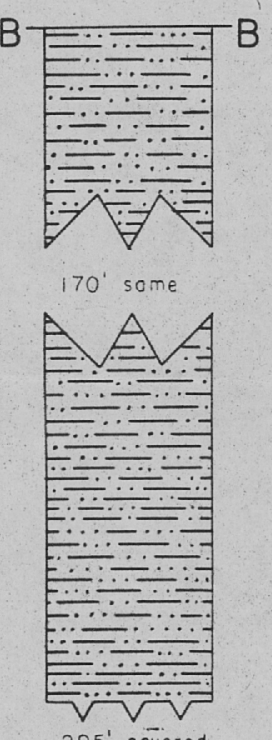

295 cover

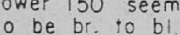

issile shale os

below; upper $50^{\prime}$

is silty, il mpy
shole os obove.

EXPLANATION
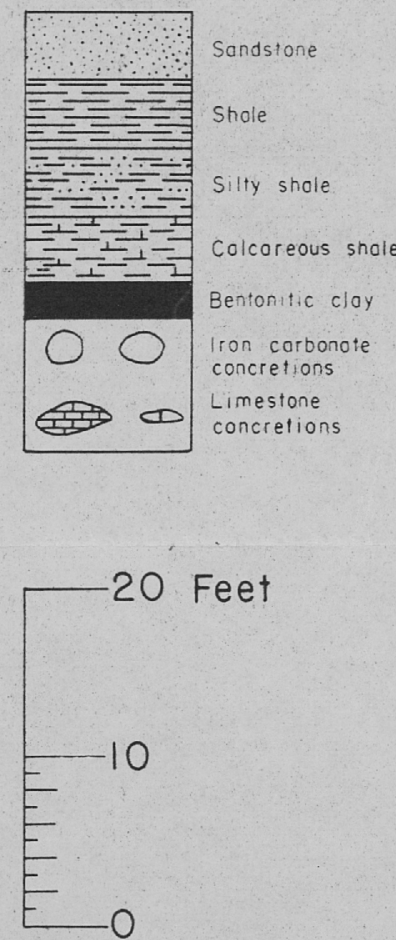

Vertical Scale

oozev-equivalent uronium

0024-yronium content (percent)

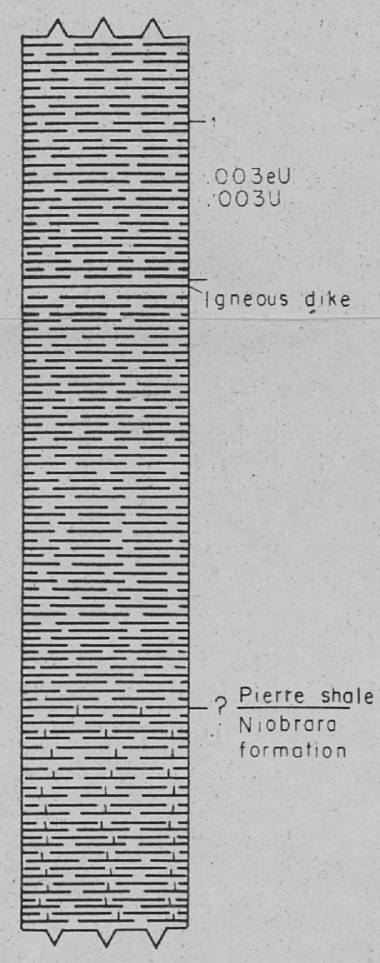



